\title{
Pendidikan "Maintain Upstream to Downstream" Untuk anak-anak di Pinggiran Sungai Kec. Cibungbulang Kab. Bogor Jawa Barat
}

\author{
Awaluddin Hidayat R. $\mathbf{I}^{\mathbf{1}}$ dan Ana Utami Zainal ${ }^{1}$ \\ ${ }^{1}$ Universitas Muhammadiyah Prof. DR. HAMKA Jl. Tanah Merdeka, Jakarta Timur, Indonesia \\ Email: awalhidayat1890@gmail.com
}

\begin{abstract}
Abstrak
Sungai merupakan sumber kehidupan bagi beberapa masyarakat di Indonesia. Keberadaan masyarakat atau pemukiman dibantaran sungai tersebut seringkali menimbulkan masalah tak terkecuali di kota-kota besar seperti Jabodetabek, dimana sungai masih mendapat tempat di hati masyarakat. Masyarakat dipinggiran sungai seringkali memanfaatkan sungai untuk keperluan mandi, mencuci, bahkan untuk kebutuhan minum. Namun kegiatan tersebut tentu akan menimbulkan masalah terutama bagi kesehatan. Efek jangka pendek maupun jangka panjang terkait perilaku tersebut belum diprioritaskan oleh masyarakat luas sehingga perlu dilakukan edukasi tentang penggunaan air yang begitu praktis dan penyediaan air bersih masyarakat yang masih kurang. Minat masyarakat yang lebih cenderung menggunakan air sungai sebagai kebutuhan seharihari sangat perlu untuk diberikan brainstorming tentang pentingnya lingkungan dan kesehatan. Mitra dalam kegiatan IbM kali ini adalah masyarakat di pinggiran sungai Desa Ciaruteunilir, Kec. Cibungbulang, Kab. Bogor Jawa Barat dengan metode branstorming permasalahan perilaku penyuluhan ke masyarakat baik dewasa maupun anak-anak Kegiatan pengabdian masyarakat dilaksanakan pada tanggal 15 Januari 2017. Metode penyuluhan yang dilakukan adalah dengan metode ceramah untuk masyarakat dewasa dan metode dongeng untuk anak-anak, memberikan pamflet dan sticker. Permasalah mitra terkait sungai adalah bahwa masyarakat di pinggiran sungai masih memiliki sikap tidak baik terhadap sungai, yakni membuang sampah di sungai, buang air besar (BAB) di sungai, melakukan aktivitas cuci mencuci di sungai yang kesemua permasalahan ini berkontribusi besar dalam kerusakan sungai. Setelah team pengabdian masyarakat melakukan kegiatan penyuluhan masyarakat berpendapat bahwa hal ini sangat bermanfaat bagi masyarakat karena team pengabdian masyarakat menjelaskan penyebab bahkan dampak serta solusi yang diberikan untuk menjaga sungai dari pengotoran manusia.
\end{abstract}

Kata Kunci : Pendidikan, maintain, pinggiran, sungai

\begin{abstract}
For some people in Indonesia, the rivers become one of the most important source of their life, especially for those who stayed on the edge of times. They use water from those rivers for bathing, washing and even as their drinks. In the big cities such as Jakarta, Bogor, Depok, Tangerang and Bekasi (Jabodetabek), those behaviors could bring a short dan long-term affects to the health of people. The target of this community service was people at Ciarunteunilir village, district Cibungbulang Bogor, West Java. Based on finding, people throw garbage into the river, defecate on it and used the water that contaminated with human waste for their daily activities. Those behaviors need to be changed because dirty water can have bad impact on their health and environmental. To educate the adult people, trainers used brainstorming and lecturing methods and fairy story become an effective media for children. Stickers and leaflets also become media to change their habits and socialize clean lifestyle. All in all, this community service could bring benefits of society and changed their perspectives of the river and healhty life.
\end{abstract}

Keywords; healthy lifestyle, on the edge, river

Format Sitasi: Hidayat, A.R.I., \& Zainal, A.U. (2018). Pendidikan "maintain upstream to downstream" untuk anak-anak di pinggiran sungai kec. Cibungbulang Kab. Bogor Jawa Barat. Jurnal SOLMA, 07(1), 90-98.

Revisi: 27-01-2018; Diterima: 28-03-2018; Diterbitkan: 19-04-2018.

doi: https://doi.org/10.29405/solma.v7i1.1046 


\section{PENDAHULUAN}

Perilaku masyarakat yang banyak mengundang reaksi lingkungan di dunia termasuk Jakarta begitu banyak terjadi, sesuai dengan beberapa aspek lingkungan hidup yang terdiri atas kesehatan tanah, kesehatan air, kesehatan udara bahkan kesehatan makanan merupakan standard utama media penilaian kulitas lingkungan di masyarakat. Kebutuhan akan air bersih yang tinggi di masyarakat Jakarta mengharuskan masyarakat untuk mencari segala sumber air bersih yang belum tentu bersumber dari air ledeng yang disediakan oleh pemerintah Jakarta, sungai merupakan salah satu sumber air yang begitu diminati beberapa masyarakat di Jakarta khsusunya masyarakat yang berada di pinggiran sungai Jakarta, dari kebutuhan yang sepintas dinilai oleh beberapa masyarakat tidak begitu berdampak langsung hingga berdampak langsung pada kesehatan masyarakat itu sendiri.

Kebutuhan air yang begitu besar melalui air sungai cukup tinggi di masyarakat umum Jakarta. Mencuci baju atau perlatan masak, penggunaan air untuk MCK (mandi, cuci dan kakus) serta bahkan untuk air minumpun di lakoni oleh masyarakat di area pinggiran beberapa anak sungai di Jakarta, dan bukan hanya terkait dengan masalah kesehatan namun lebih kepada maslaha kasus banjir yang merugikan masyarakat dan juga lingkungan belakangan ini. Penyakit diare masih merupakan masalah kesehatan masyarakat di negara berkembang seperti di Indonesia, karena morbiditas dan mortalitas nya yang masih tinggi. Survei morbiditas yang dilakukan oleh Subdit Diare, Departemen Kesehatan dari tahun 2000 s/d 2010 terlihat kecenderungan insidens naik, serta kasus banjir terjadi sebanyak 535 kasus banjir terjadi di Indonesia, dengan korban luka-luka sebanyak 1.942 juta jiwa per tahun 2016 melalui data BNPP (Badan nasional penanggulangan bencana).

Hilir sungai yang ada di ciliwung merupakan hilir yang bersmber dari hulu yang panjang dari kab. Bogor, kasus banjir yang terjadi di Jakarta tidak serta merta terjadi tanpa campur tangan perilaku masyarakat di beberapa titik sungai di sepanjang hulu sungai. Wilayah fisiografi Jakarta terletak pada dataran rendah berupa flood plains yang berasal dari gunung Gede-Pangrango, Salak dan Halimun, membentang mulai dari daerah Serang sampai Cirebon yang mengalami proses pelipatan. Wilayah Jakarta termasuk pada wilayah endapan yang potensial sebagai tempat genangan air. Potensi-potensi genangan ini merupakan faktor yang perlu dipertimbangkan bagi sebagian besar wilayah Jakarta. Faktor kondisi lokasi Jakarta yang berada pada dataran rendah, juga karena terjaddi penumpukan sampah di sungai ciliwung, kondisi sungai di hilir dipangruhi besar oleh kondisi hulu juga 
merupakan salah satu masalah yang perlu mendapat perhatian khusus, perilaku membuang sampah di sungai oleh masyarakat dipinggiran sungai dari hulu hingga hilir berakibat pada kondisi akhir sungai Ciliwung Jakarta. Banjir dijakarta adalah salah satu proses alam, banjir terjadi karena debit air sungai yang sangat tinggi hingga melampaui daya tampung saluran sungai lalu meluap ke daerah sekitarnya. Debit air sungai yang tinggi terjadi kerana curah hujan yang tinggi, sementara itu, banjir juga dapat terjadi karena kesalahan manusia diantaranya membuang sampah disungai.

Perilaku masyarakat di era ini begitu mengalami kemunduran terutama perilaku hidup bersih dan sehat (PHBS) baik bagi diri sendiri atau lingkungan, masyarakat yang dengan pendidikan rendah jika dihadapkan pada perilaku kesehatan maka tidak semua dapat menjalani dengan baik, dikarenakan kurnagnya motivasi dan juga sosialisasi dari instansi terkait. Perilaku membuang sampah sembarangan ini, tidak mengenal tingkat pendidikan maupun status sosial. Keberadaan sampah di kehidupan sehari-hari tak lepas dari tangan manusia yang membuang sampah sembarangan, masyarakat di tepian sungai menganggap barang yang telah dipakai tidak memiliki kegunaan lagi dan membuang dengan seenaknya sendiri. Kurang kesadaran akan pentingnya kebersihan sungai menjadi faktor yang paling dominan, di samping itu kepekaan masyarakat terhadap lingkungan harus dipertanyakan. Mereka tidak mengetahui bahaya apa yang akan terjadi apabila tidak dapat menjaga lingkungan sekitar dalam hal ini adalah sungai. Salah satu bentuk perilaku masyarakat adalah membuang sampah di sungai dengan alasan wajar karena sudah menjadi kebiasaan dari nenek moyang, atau malas dikarenakan jarak sungai dan rumah begitu dekat sehingga untuk menjangkau tempat sampah dirasakan jauh ataupun karena tidak adanya tempat sampah yang disediakan di sekitar rumah masyarakat.

Kondisi ini menyebabkan lingkungan di sekitar tepi sungai terlihat sangat kotor akibat tumpukan sampah, lalat beterbangan, banyak tikus dan nyamuk, bahkan menyebarkan aroma yang tidak sedap dan dampak terburuk adalah masyarakat hilir yang juga ikut merasakan masalah kesehatan dan lingkungan yang terjadi baik itu diare atau kasus banjir tiap tahun di Jakarta.

Sungai adalah tempat-tempat dan wadah-wadah serta jaringan pengaliran air mulai darimata air sampai muara dengan dibatasi kanan dan kirinya serta sepanjang pengalirannya oleh garis sempadan. Sungai sebagai sumber air merupakan salah satu sumber daya alam yang mempunyai fungsi serbaguna bagi kehidupan dan penghidupan 
manusia. Sungai harus dilindungi dan dijaga kelestariannya, ditingkatkan fungsi dan kemanfaatannya, dan dikendalikan daya rusaknya terhadap lingkungan. Perlindungan sungai adalah upaya pengamanan sungai terhadap kerusakan-kerusakan yang disebabkan oleh tindakan manusia dan alam dan juga mengatasi dampak kesehatan yang terjadi dari permasalah tersebut. Pengembangan sungai adalah upaya yang dilakukan untuk meningkatkan kemanfaatan fungsi sungai sebesar-besarnya tanpa merusak keseimbangan sungai dan lingkungannya. Penggunaan sungai adalah upaya memanfaatkan sungai. Pengendalian sungai adalah upaya untuk lebih memantapkan aliran sungai sepanjang tahun, guna memperoleh kemanfaatan sungai sebesa-besarnya, dan mengurangi/meniadakan daya rusak air terhadap sungai dan lingkungannya.

Sungai Ciliwung melewati dua provinsi, yaitu provinsi Jawa Barat dan Provinsi DKI Jakarta. Lebih tepatnya bagian hulu sungai ciliwung berada di gunung tenalag mandalawangi (Kab. Bogor) dan bagian hilir bermuala di teluk Jakarta. Sungai Ciliwung sendiri panjang bentang mencapai $76 \mathrm{~km}$ dan luas DAS mencapai $322 \mathrm{~km}^{2}$. DAS Ciliwung memmpunyai bentuk aliran menyempit di bagian hilir dan lebar di bagian hulu dengan aliran air dan arah selatan ke utara Jakarta.

Masyarakat yang dianggap penting untuk diberikan pendidikan berupa penyuluhan terkait masalah kesehatan sungai dan dampak kesehatan dari perialku membuang sampah sembarangan ini dan yang menjadi sasaran adalah yang bermukim di sepanjang sungai di beberapa titik di bogor, salah satunya di sungai Cisampay Bogor, data jumlah jiwa yang bermukim di sekitar sungai adalah 280 jiwa yang terdiri dari 113 laki-laki dan 187 perempuan, dan dari sekeluruhan tersebut terdapat 64 anak-anak dengan kisaran umur 717 tahun.

\section{MASALAH}

Lokasi sungai di hulu di pilih dikarenakan sebagian besar sumber masalah penumpukan sampah bukan hanya diakibatkan oleh sampah dari Jakarta saja melainkan sampah yang ikut hanyut dari hulu. Sebagian besar sosialisasi msyarakat hanya terfokus pada masyarakat umum dengan sounding "jangan membuang sampah di sembarang tempat" tapi bentuk promosi kesehatan tidak ditujukan kepada masyarakat pinggiran sungai sehingga tidak dapat sepenuhnya dijalani oleh masyarakat khususnya pinggiran sungai, masyarakat dewasa yang dinilai dapat memberikan pemahaman kepada masyakarat lain disekitar lokasi tersebut dan juga memberikan pengajaran kepada keluarga termasuk 
anak-anak mereka, tim pelaksana nilai cukup untuk mengatasi polemic perialku membuang sampah di sungai ini, namun tidak dapat diserahkan begitu saja, anak-anak harus tetap mendapat sentuhan langsung oleh penyuluh kesehatan karena perlu dipastikan mereka mendapat informasi langsung dan juga tim pelaksana dapat melihat langsung dan menggali informasi dari anak-anak di lokasi pinggiran sungai tersebut, melalui sekolah skolah yakni PAUD, TK, SD, SMP hingga SMA yang tinggal di pinggiran sungai, tim pelaksana berharap dapat tersalurkan dengan baik informasi ini dan dapat menurunkan angka perilaku membuang sampah di sungai.

\section{METODE PELAKSANAAN}

\section{Solusi yang Ditawarkan}

Dalam program pengabdian berupa penyuluhan yang dilaksanakan oleh team penyuluh dengan system ceramah dan diskusi, beberapa bahan penyuluhan yang diberikan dinilai sangat bermanfaat dan sesuai dnegan tema dari pengabdian masyarakat kali ini, dengan tema menjaga kebersihan hulu sungai agar hilir sungai tetap terjaga. Sasaran masyarakat dan dewasa dilakukan perbedaan dalam cara penyuluhan, pada anak-anak dilakukan dengan system penyuluhan dongeng oleh pendongeng, anak-anak terlihat sangat antusias dengan kegiatan ini dikarenakan system penyuluhan di buat menarik dan lucu.

Penyuluhan yang dilakukan menrupakan solusi yang diberikan oleh team pengabdian masyarakat sebagai cara untuk mengatasi perilaku masyarakat yang masih tidak baik dalam hubunganya dengan menjaga kebersihan sungai karena berdasasrkan diskusi dengan peserta pengabdian masyarakat, mengakui bahwa masyarakat belum paham akan penyebab dampak serta cara untuk mengatasi permasalahan yang berhubungan dengan sungai, sehingga masyarakat merasakan manfaat dari kegiatan yang dilakukan.

\section{Metode Pelaksanaan}

Metode yang dilaksanakan dalam tahap ini adalah brainstorming tentang bentuk aktivitas masyarakat yang berkonstribusi dalam pengotoran sungai, memberikan penyuluhan dengan cara ceramah menggunakan media presentasi serta membagikan pamphlet bagi orang dewasa, menggunakan metode penyuuluhan dengan metode mendongeng kepada anak-anak yang kesemuanya bertujuan agar isi penyuluhan dapat tersampaikan sesuai dengan sasaran umur dan juga tingkat pendidikan. 


\section{PEMBAHASAN}

Pelaksanaan ini diawali dengan melakukan survey awal terlebih dahulu dengan mendatangi ketua yayasan desa mentari yang dalam hal ini merupakan mitra dalam pengabdian masyarakat untuk meminta persetujuan akan kegiatan yng akan dilaksanakan nantinya dan juga dapat mengumpulkan masyarakat yang teridir dari dewasa dan anakanak guna menghadiri kegiatan penyuluhan. Kegiatan pengbdian masyarakat dengan tema "Pendidikan maintain upstream to downstream" dilaksnakan di pinggiran sungai Desa Ciaruteunilir, Kec. Cibungbulang, Kab. Bogor Jawa Barat, Minggu, 15 Januari 2017. Pemilihan waktu dan tanggal tersebut disesuaikan dengan kondisi masyarakat yang memiliki waktu yang lebih banyak di hari libur serta menyesuaikan pula dengan waktu dari masing-masing anggota tim pelaksana pengabdian masyarakat. Masyarakat dewasa dan anak-anak merupakan sasaran yang dinilai penting dalam kegiatan ini dikarenakan dua sasaran inilah yang selalu bersentuhan langsung dengan aktifitas di pinggiran sungai.

Melalui observasi langsung dan wawancara di Desa Cirautenilir bahwa sungai dalam keadaan kotor dan tidak terpelihara dengan bik, akibat aktivitas masyarakat di pinggiran sungai dan rendahnya kesadaran akan pemeliharaan kebersihan sungai dinilai menjadi penyebab utama. Melakukan buang air besar (BAB) di sungai membuang sampah sembarangan ke sungai serta melakukan aktivitas cuci mencuci adalah jenis aktivitas yang berkontribusi dalam pengotoran sungai di desa ini.

Masyarakat dewasa terlihat bersemangat dan antusias mendengarkan tentang isi bahan penyuluhan yang dinilai sangat bermanfaat bagi masyarakat ini di lihat dari banyaknya masyarakat yang mengajukan pertanyaan terkait permasalahan lingkungan yang dihadapi. Anak-anak yang juga enjadi sasaran dalam kegiatan pengabdian ini juga turut senang karena team pengabdian menghadirkan pendongeng yang memberikan penyuluhan dengan cara yang sangat disukai anak-anak melalui cerita dongen lucu yang didalamnya terdapat isi pesan moral terkait pentingnya menjaga kebersihan sungai, ini dapat dilihat dengan canda dan tawa anak-anak yang merasa senang menyaksikan pendongeng dalam menyampaikan pesan penyuluhan.

Ada 3 jenis limbah rumah tangga yaitu limbah pertama berupa sampah, kemudian limbah kedua berupa air limbah yang dihasilkan dari kegiatan mandi dan mencuci, kemudian limbah ketiga adalah kotoran yang dihasilkan manusia. Limbah-limbah ini, jika tak dikelola dengan baik, dapat berpotensi tinggi mencemari lingkungan sekitar 
Sampah merupakan material sisa yang tidak diinginkan setelah berakhirnya suatu proses. Sampah merupakan didefinisikan oleh manusia menurut derajat keterpakaiannya, dalam proses-proses alam sebenarnya tidak ada konsep sampah, yang ada hanya produkproduk yang dihasilkan setelah dan selama proses alam tersebut berlangsung. Akan tetapi karena dalam kehidupan manusia didefinisikan konsep lingkungan maka sampah dapat dibagi menurut jenis-jenisnya. Berdasarkan sumbernya sampah alam, sampah manusia dan sampah konsumsi

Berdasarkan sifatnya:

1. Sampah organik dapat diurai (degradable)

Sampah Organik, yaitu sampah yang mudah membusuk seperti sisa makanan, sayuran, daun-daun kering, dan sebagainya. Sampah ini dapat diolah lebih lanjut menjadi kompos

2. Sampah anorganik tidak terurai (undegradable)

Sampah Anorganik, yaitu sampah yang tidak mudah membusuk, seperti plastik wadah pembungkus makanan, kertas, plastik mainan, botol dan gelas minuman, kaleng, kayu, dan sebagainya. Sampah ini dapat dijadikan sampah komersil atau sampah yang laku dijual untuk dijadikan produk lainnya. Beberapa sampah anorganik yang dapat dijual adalah plastik wadah pembungkus makanan, botol dan gelas bekas minuman, kaleng, kaca, dan kertas, baik kertas koran, HVS, maupun karton.

3. Sampah manusia.

Sampah manusia (human waste) adalah istilah yang biasa digunakan terhadap hasil-hasil pencernaan manusia, seperti feses dan urin. Sampah manusia dapat menjadi bahaya serius bagi kesehatan karena dapat digunakan sebagai vektor (sarana perkembangan) penyakit yang disebabkan virus dan bakteri.

Air sungai termasuk ke dalam air permukaan yang banyak digunakan oleh masyarakat. Pada masyarakat pedesaan, air sungai masih digunakan untuk mencuci, mandi, sumber air minum dan juga pengairan sawah.. Dalam kegiatan sehari-hari, masyarakat menggunakan air sungai untuk hampir semua kegiatan rumah tangga. Mereka mencuci baju dan piring, mandi, dan juga minum menggunakan air sungai.

Masyarakat yang tinggal di sekitar sungai tentunya memanfaatkan sungai dalam kehidupan sehari-hari mereka, baik mencuci, memasak, mandi maupun minum. Ketika mereka menggunakan air sungai yang telah tercemar, tentu akan ada efek samping yang 
dirasakan. Efek samping utama yang diterima oleh masyarakat ialah penyakit. Penyakit yang terjadi umumnya ialah penyakit diare. Diare dapat terjadi akibat protozoa maupun bakteri. Umumnya diare disebabkan oleh bakteri dalam air. Air yang kotor digunakan untuk mencuci sehingga bakteri tertinggal di benda-benda yang kemudian digunakan oleh warga.

Selain diare, penyakit lain yang dapat menyerang warga ialah cacingan. Cacingan terjadi akibat infeksi dari telur cacing yang masuk ke tubuh manusia. Penyakit ini ditandai dengan perut buncit namun kondisi tubuh yang kurus. Penyakit kulit juga merupakan penyakit yang umum diderita masyarakat pengguna air tercemar. Biasanya gatal-gatal ialah ciri utama yang terjadi sebelum penyakit kulit menjadi lebih parah. Hal ini disebabkan karena adanya kandungan mineral yang beracun untuk kulit

Melihat penyebab serta dampak kesehatan yang menimpa masyarakat pinggiran sungai sehingga dengan cara yang menarik team pengabdian melakukan sosialisasi guna merubah perilaku masyarakat yang kurang baik oleh masyarakat terhadap sungai, melihat aktivitas penyuluhan masyarakat dewasa maupun anak-anak terlihat sangat antusias dan merasa senang dikarenakan sebelumnya masyarakat mengakui belum adanya penyuluhan yang berfokus pada kebersihan sungai, sehingga masyarakat memberikan banyak pertnyaan tentang bagaiman menjaga sungai dan merubah perilaku mereka serta cara mengatasi dampak kesehatan yang menimpa masyaraat, kesemua pertanyaan kami jawab denga baik dan masyarakat merasa banyak mendapat informasi dari penyuluhan yang dilakukan team pengabdian masyarakat.

\section{KESIMPULAN}

Terdapat kesimpulan yang diperoleh dari kegiatan pengabdian masyarakat yakni, Kerjasama kegiatan oengmabdian masyarakat antara Program Studi Kesehatan Masyarakat dengan Mitra pengabdian masyarakat yakni masyarakat pinggiran sungai di Desa Ciaruteunilir, Kec. Cibungbulang, Kab. Bogor Jawa Barat, tanggal 15 Januari 2017, adanya peningkatan pengetahuan masyarakat dewasa dan anak-anak tentang sanitasi sungai melalui upaya menjaga kebersihan sungai dan Melibatkan seluruh masyarakat di pinggiran sungai di Desa Ciaruteunilir, Kec. Cibungbulang, Kab. Bogor Jawa Barat dalam upaya meenjaga kebersihan sungai. 


\section{UCAPAN TERIMA KASIH}

Terimakasih Kepada Lppm (Lembaga Penelitian Pengabdian Masyarakat) Sebagai Pemberi Dana Kegiatan Pendidikan “Maintain Upstream To Downstream” Untuk AnakAnak Di Pinggiran Sungai Kec. Cibungbulang, Kab. Bogor Jawa Barat.

Terimakasih kepada masyarakat pinggiran sungai Desa Ciaruteunilir, Kec. Cibungbulang, Kab. Bogor sebagai mitra pelaksanaan kegiatan dan membantu dalam pelaksaan kegiatan Pendidikan "Maintain Upstream To Downstream” Untuk Anak-Anak Di Pinggiran Sungai Kec. Cibungbulang, Kab. Bogor Jawa Barat

\section{DAFTAR PUSTAKA}

Ary, D., Jacobs, L.C., \& Razavieh, A. (1976). Pengantar Penelitian Pendidikan. Terjemahan oleh Arief Furchan. (1982). Surabaya: Usaha Nasional

Prahmana, R.C.I. (2012). Pendesainan Pembelajaran Operasi Bilangan Menggunakan Permainan Tradisional Tepuk Bergambar Untuk Siswa Kelas III Sekolah Dasar (SD). Unpublished Thesis. Palembang: Sriwijaya University.

E. Damanhuri, Pengelolaan Limbah dalam Life Cycle Analysis (LCA) -Tinjauan Limbah Cair, Limbah Padat dan B3, Pelatihan Product Life Cycle Analysis, PPLH ITBH, 315Mei 1999

G.H. Tchobanoglous, H. Theissen, S.A. Vigil: Integrated Solid Waste Management, McGraw Hill, 1993.

D.G. WILSON (Editor): Handbook of Solid Waste Management, Van Nosbtrand Reinhold Company, 1977.

BPPT, Model Pengelolaan Persampahan Perkotaan, Deputi Pengkajian Kebijakan Teknologi, Oktober 2002

SK SNI 19-2454-1991 dan SNI 19-3242-1994: Tata Cara Pengelolaan Sampah Perkotaan

Kementrian Lingkungan Hidup: Statistik Pengelolaan Sampah Tahun2008.

Kementrian Riset Tekhnologi, dan Pendidikan Tinggi: Panduan pelaksanaan penelitian dan pengabdian kepada masyarakat di perguruan tinggi edisi X: 2016

Prahmana, R.C.I. (2013). Designing Division Operation Learning in the Mathematics of Gasing. Proceeding in The First South East Asia Design/Development Research (SEA-DR) Conference 2013, 391-398. Palembang: Sriwijaya University. 